\title{
Steps toward making a journal more relevant
}

\author{
Bo Söderström
}

\section{LOOKING BACK}

I took up the position as Editor-in-Chief of Ambio almost 7 years ago. At the same time, we changed publishers from Allen Press to Springer. Since then, we have continued our work to make the journal more relevant for addressing the evolving needs of researchers and society. For example, we have streamlined the review process, cut down on manuscript handling times, offered authors the possibility to publish open access should they so wish, and introduced open calls to publish thematic issues on topical subjects. We have published a total of 22 special issues, and regular full-text articles are downloaded at an ever-increasing rate (having surpassed half a million per year in 2015). We can look back at many success stories, but this is not the time to be complacent. Now, more than ever, Ambio occupies an important niche in a global society that needs to build environmental policies on the best available evidence delivered by scientific research.

\section{ASSOCIATE EDITORS}

I am privileged to work closely with an excellent group of 17 associate editors across different areas of expertise. We have face-to-face editorial meetings once per year when we discuss the status and future development of the journal. Strategy discussions via e-mail are also common throughout the year. The associate editors have various international backgrounds, but all of them have until recently been based in Scandinavia. This has worked well, but we are always seeking ways to improve, so we are slowly heading towards more international representation among the associate editors. This is showcased by our two most recently recruited associate editors: (1) Jeffrey A. McNeely is currently an environmental specialist at the Asian Development Bank in Thailand. Previously, he worked for 30 years with the International Union for Conservation of Nature and Natural Resources (IUCN). (2) Wiebren J. Boonstra currently works at the Stockholm Resilience Centre and Rutgers University, New Jersey. He did his dissertation work at Wageningen University in the Netherlands. Both Jeff and Wynand (as they like to be called) have done excellent peer review work for Ambio over the last decade.

\section{UPCOMING SPECIAL ISSUES}

At the end of 2016, we will publish a special issue titled Gender perspectives in resilience, vulnerability and adaptation to global environmental change. This is an excellent example of interdisciplinary science that can find a suitable outlet in Ambio. We are pleased that nowadays, Ambio has a reasonably balanced gender composition among both editors and Advisory Board members. In 2017, we can also look forward to three special issues that directly or indirectly target the Arctic, one of our focus regions over the more than 45 years of our publishing history. Climate Change, Economy and Society in the Arctic Ocean: A FP7 European Union project within the program Arctic Climate Change, Economy and Society (ACCESS) assessed the main impacts of climate change on the Arctic Ocean's geophysical variables and how these impending changes could be expected to have direct and indirect impacts on socio-economic activities such as transportation, marine sea food production, and resource exploitation. Synthesis of Greenland Ecosystem Monitoring: Greenland Ecosystem Monitoring (GEM) is an integrated monitoring and long-term research program on 
ecosystems and climate change effects and feedbacks in the Arctic. Since 1994, the program has established a coherent and integrated understanding of the functioning of ecosystems in a highly variable climate, which is based on comprehensive, long-term interdisciplinary datasets. Finally, Goose management-from local to flyway scale looks at the series of problems and challenges that need to be addressed by a range of stakeholders and government agencies for effective management of geese populations.

\section{THE ADVISORY BOARD}

In 2016, we decided to discontinue the Editorial Board and replace it with an Advisory Board that has been given a clear mandate to advise and support Ambio editors. We are honored that all of the invited scientists accepted our invitations without any hesitation. We highly value the judgement of these prominent researchers (see Table 1), most of whom have been authors of several articles published in Ambio. The endorsement of these Ambio ambassadors will further strengthen our journal in the future. Recently, the editors asked Advisory Board members to respond to some of the most pressing issues Ambio is currently facing. Most journal editors will recognize these familiar problems. We received lots of specific advice and the editors will work on implementing many of these valuable suggestions.

\section{Input from the Advisory Board to editor queries}

To indicate the kinds of advice that was provided by $\mathrm{Am}$ bio's Advisory Board, the following provides the highlights of answers to questions posed by the editors.

\section{Scope}

Editors: Ambio has a very broad scope. Should we restrict the scope to make Ambio a more "targeted" journal?

Advisory Board: Unanimous views from all members recommended that Ambio should not become a more targeted journal. Its main strength is that the journal also publishes multi/interdisciplinary research. If anything, we should push harder to become a more interdisciplinary journal and market this even more effectively.

\section{Increase awareness}

Editors: The number of submissions to Ambio has increased by more than $50 \%$ since 2010 . Although this development is encouraging, a further increase of high- quality submissions is much desired. How can we become more well-known among potential contributors?

Advisory Board: Ambio seems to be medium- to wellknown journal among the colleagues of Advisory Board members. It would be helpful to market the journal's inter/multidisciplinarity aspects even more, and valuable suggestions included increasing awareness by encouraging Advisory Board members and other high-profile researchers to submit their best work to us. Most think that it would be good to always use the sub-title in all communication, i.e., "Ambio-A Journal of the Human Environment."

\section{Peer review}

Editors: We have continuously worked on improving the quality and speed of the peer review process in Ambio. But like so many other journals, we still struggle with high decline rates to our invitations to review. What incentives can encourage higher rates of acceptance of review invitations?

Advisory Board: Incentives for increasing the chance of reviewers accepting the invitations include (1) creating personalized invitations; (2) submitting interesting and clearly written abstracts; (3) reducing detail on reviewer forms; (4) better screening by the editors for quality prior to inviting reviewers; (5) considering talented young scientists as reviewers; (6) authors agreeing to review at least one manuscript for every manuscript published in the journal; (7) ranking of reviewers (by editors) in order to identify and avoid those who consistently underperform, while enlisting those that outperform more frequently (but with a cap on number of invitations per year); (8) providing annual feedback to reviewers as more formal recognition for their valuable contribution to the journal; (9) creating a sense of journal loyalty for a group of reviewers; and (10) further building up the reputation of the journal so that it attracts good-quality manuscripts.

\section{Marketing of published articles}

Editors: The number of downloads of full-text articles has increased quite dramatically in recent years, and in 2015 we passed half million downloads per year. What is the most effective way to market individual articles?

Advisory Board: The following suggestions were given: (1) encourage entry of articles into Faculty of 1000, COMPASS, and similar outlets; (2) target scientific societies to forward information regarding newly published articles; (3) help authors in crafting efficient tweets; (4) tag the twitter address of the author and when Springer uses twitter; (5) flag those who download particular papers and suggest other downloads that have a similar topic; (6) provide Editor's Choice in each issue, and/or encourage 
Table 1 The 21 members of the new Advisory Board to Ambio

\begin{tabular}{|c|c|c|}
\hline Name & Title, Affiliation, Country & Areas of expertise \\
\hline Neil Adger & Professor of Geography, University of Exeter, United Kingdom & $\begin{array}{l}\text { Sustainability, resilience, ecological economics, human } \\
\text { geography }\end{array}$ \\
\hline Heidi J. Albers & $\begin{array}{l}\text { Professor of Conservation Economics, University of Wyoming, } \\
\text { U.S.A. }\end{array}$ & $\begin{array}{l}\text { Environment and natural resource economics, } \\
\text { development economics }\end{array}$ \\
\hline Jesper H. Andersen & $\begin{array}{l}\text { Chief Scientist, NIVA Denmark Water Research, Denmark } \\
\text { Visiting Research Professor, MRC/SYKE }\end{array}$ & $\begin{array}{l}\text { Eutrophication, ecosystem-based management, marine } \\
\text { biodiversity }\end{array}$ \\
\hline Leif Anderson & $\begin{array}{l}\text { Professor of Marine Chemistry, University of Gothenburg, } \\
\text { Sweden }\end{array}$ & $\begin{array}{l}\text { Marine chemistry, oceanic carbon cycle, ocean } \\
\text { acidification }\end{array}$ \\
\hline Alpina Begossi & $\begin{array}{l}\text { Professor, University of Santa Cecilia, Brazil } \\
\text { Research Director, Fisheries and Food Institute, Brazil } \\
\text { Researcher, State University of Campinas, Brazil }\end{array}$ & Fisheries, ethnobiology, human ecology \\
\hline Merete Bilde & Professor of Chemistry, Aarhus University, Denmark & $\begin{array}{l}\text { Atmospheric physical chemistry, aerosols and clouds, } \\
\text { air pollution }\end{array}$ \\
\hline Erik Bonsdorff & Professor of Marine Biology, Åbo Akademi University, Finland & $\begin{array}{l}\text { Marine ecology, benthos, biodiversity, hypoxia, climate } \\
\text { change }\end{array}$ \\
\hline Shixiong Cao & $\begin{array}{l}\text { Professor of Economics and Management, Beijing Forestry } \\
\text { University, China }\end{array}$ & $\begin{array}{l}\text { Socioeconomics, ecological restoration, sustainable } \\
\text { development, soil, afforestation }\end{array}$ \\
\hline Terry V. Callaghan & $\begin{array}{l}\text { Professor of Arctic Ecology, University of Sheffield, United } \\
\text { Kingdom } \\
\text { Professor of Botany, Tomsk State University, Russia }\end{array}$ & $\begin{array}{l}\text { Ecology of Arctic plants, animals, and ecosystem } \\
\text { processes, changes in climate }\end{array}$ \\
\hline Robin L. Chazdon & $\begin{array}{l}\text { Professor of Tropical Ecology, University of Connecticut, } \\
\text { U.S.A. }\end{array}$ & $\begin{array}{l}\text { Forest dynamics, succession, forest regeneration, } \\
\text { tropical biology }\end{array}$ \\
\hline Carl Folke & $\begin{array}{l}\text { Science Director, Stockholm Resilience Centre, Sweden } \\
\text { Director, Beijer Institute of Ecological Economics, Royal } \\
\text { Swedish Academy of Sciences, Sweden }\end{array}$ & $\begin{array}{l}\text { Social-ecological systems resilience, ecosystem } \\
\text { management, governance }\end{array}$ \\
\hline Dagmar Haase & $\begin{array}{l}\text { Professor of Landscape Ecology, Humboldt University, } \\
\text { Germany }\end{array}$ & Urban ecology, land-use modeling, ecosystem services \\
\hline Raija Laiho & $\begin{array}{l}\text { Professor of Peatland Forestry, Natural Resources Institute } \\
\text { Finland, Finland }\end{array}$ & $\begin{array}{l}\text { Peatland ecology, forest ecology, forestry in peatlands, } \\
\text { organic soils, carbon cycling }\end{array}$ \\
\hline Jerry M. Melillo & $\begin{array}{l}\text { Distinguished Scientist, The Ecosystems Center, Marine } \\
\text { Biological Laboratory, U.S.A. }\end{array}$ & $\begin{array}{l}\text { Climate change, carbon and nitrogen dynamics, net } \\
\text { primary productivity }\end{array}$ \\
\hline Mohan Munasinghe & $\begin{array}{l}\text { Chairman, Munasinghe Institute for Development, MIND, } \\
\text { Colombo, Sri Lanka }\end{array}$ & $\begin{array}{l}\text { Environmental economics, sustainable development, } \\
\text { energy, climate change }\end{array}$ \\
\hline Karen O’Brien & Professor of Human Geography, University of Oslo, Norway & $\begin{array}{l}\text { Climate change, adaptation, social transformations, } \\
\text { human security }\end{array}$ \\
\hline Catherine Pickering & Professor of Plant Ecology, Griffith University, Australia & $\begin{array}{l}\text { Alpine ecology, recreation ecology, sustainable } \\
\text { tourism, climate change }\end{array}$ \\
\hline Terry D. Prowse & $\begin{array}{l}\text { Professor and Research Chair, University of Victoria, Canada } \\
\text { Senior Scientist, Environment and Climate Change, Canada } \\
\text { Water \& Climate Impacts Research Centre (W-CIRC) }\end{array}$ & $\begin{array}{l}\text { Cold-regions hydrology, freshwater ice, climate } \\
\text { change, hydro-ecology }\end{array}$ \\
\hline Sybil Seitzinger & $\begin{array}{l}\text { Professor, University of Victoria, Canada } \\
\text { Director, Pacific Institute for Climate Solutions, Canada }\end{array}$ & $\begin{array}{l}\text { Nutrient biogeochemistry in coastal marine and } \\
\text { freshwater ecosystems }\end{array}$ \\
\hline Sverker Sörlin & $\begin{array}{l}\text { Professor of Environmental History, KTH Royal Institute of } \\
\text { Technology, Sweden }\end{array}$ & $\begin{array}{l}\text { Environmental history, history of science, research } \\
\text { policy }\end{array}$ \\
\hline Martine Visser & $\begin{array}{l}\text { Associate Professor of Economics, University of Cape Town, } \\
\text { South Africa }\end{array}$ & Natural resource economy \\
\hline
\end{tabular}

Springer to craft a press release for a particularly interesting paper; (7) encourage authors to add open access articles published to ResearchGate and Academia.com; and (8) use tools like Editors' Vox and The Conversation.

\section{Special issues}

Editors: Ambio publishes three special issues on topical research themes each year. These are published as 
supplements on top of the eight regular issues published each year. We have an open call for submission of proposals twice per year and receive twice as many proposals as we can publish. The themes of special issues are wideranging, although there is a strong focus on the Baltic and Arctic regions. Would it be a better solution to solicit proposals on themes we decided by the editorial board?

Advisory Board: The bottom-up process used today works well, but the option to submit proposals for special issues should be announced more widely on the web and elsewhere. Ambio should also track the upcoming development of scientific reviews being conducted by various international groups, particularly those with a multi-/interdisciplinary focus and then approach such groups for potential publication. Members of the Advisory Board sent us 28 themes for future Special Issues!

If you have ideas for improving Ambio's quality and/or its relevance to society, please send me an e-mail.

\section{Bo Söderström \\ Editor-in-Chief, Ambio}

The Royal Swedish Academy of Sciences, Sweden. e-mail: bo.soderstrom@kva.se 